Kleczkowski, J. \& Kleczkowski, A. (1956). J. gen. Microbiol. 14, 449-459

\title{
Effects of Clupein and of its Degradation Products on a Rhizobium Bacteriophage, on its Host Bacterium and on the Interaction between the two
}

\author{
By J. KLECZKOWSKI AND A. KLECZKOWSKI \\ Rothamsted Experimental Station, Harpenden, Hertfordshire
}

SUMMARY : Clupein at $0 \cdot 02-0 \cdot 05 \%$ in the liquid nutrient medium used to cultivate nodule bacteria, rapidly killed the bacteria and slowly inactivated a bacteriophage that attacked them. When added to a bacterial culture in liquid medium before adding phage, clupein prevented phage and bacteria from combining; when added after the two had combined, clupein interrupted further stages of phage-host interaction. Clupein at $0.0016 \%$ acted bacteriostatically and slowed phage multiplication but did not stop it.

Trypsin and chymotrypsin hydrolyse clupein, trypsin breaking about twice as many peptide bonds as chymotrypsin. At a concentration corresponding to $0.02-$ $0.05 \%$ clupein, the peptides produced by chymotrypsin acted bacteriostatically in the liquid nutrient medium; the peptides inactivated phage much more slowly than did intact clupein, and they inhibited phage multiplication by interfering with the combination between phage and host. When added after phage and bacteria had combined, the peptides did not interfere with further stages of phage-host interaction. The smaller peptides produced by trypsin had no effect on host bacteria, phage, or phage/host interaction.

Phage preparations partially inactivated by clupein had their activity partially restored by incubation with trypsin or chymotrypsin.

Clupein, but none of its hydrolytic products, made phage with much non-phage material sedimentable by slow-speed centrifugation.

Bawden \& Pirie (1937) found that tobacco mosaic virus was precipitated by clupein. Kleczkowski (1946) showed that, like many other proteins, the virus was precipitated only within the $\mathrm{pH}$ range in which it was charged oppositely to clupein. Pairs of some other proteins also precipitate each other in such conditions, presumably because electrostatic attraction leads to combination and mutual discharge.

Some protamines, particularly clupein, are highly toxic to animals when injected intravenously (Thompson, 1900). Clupein also inhibits the infectivity of tobacco mosaic virus when present in the inoculum, but it does not destroy the virus (Kleczkowski, 1946). The inhibitory effect of clupein can be diluted out, and virus with its original infectivity can be re-isolated from mixtures with clupein (Bawden \& Pirie, 1937). Protamines do not seem to destroy some animal viruses, and have been used to fractionate crude virus preparations, either by precipitating viruses and leaving behind some other materials, or vice versa (Chambers \& Henle, 1941; Warren, Weil, Russ \& Jeffries, 1949, 1950). The work described in this paper was started to see whether clupein could be used to fractionate preparations of a rhizobium bacteriophage; it developed into a study of effects of clupein and of some of its degradation products on the phage, the host bacterium and their interaction. 


\section{METHODS}

The phage for a strain of nodule bacteria (Rhizobium leguminosarum, strain $317)$, the media and the method of poured plates for obtaining plaques were the same as those used previously (Kleczkowski \& Kleczkowski, 1954a, b). Bacterial cultures in liquid medium lysed by the phage and passed through a Chamberland L3 filter are referred to as 'stock cultures' of the phage.

Clupein sulphate was obtained from The British Drug Houses Ltd. Unless otherwise stated, the $\mathrm{pH}$ value of its solutions was adjusted to 7 .

Preparations of crystallized trypsin and chymotrypsin were obtained from beef pancreas as described by Northrop, Kunitz \& Herriot (1948). Chymotrypsinogen was crystallized eight times, and converted into chymotrypsin, which was crystallized twice. Trypsin was crystallized once. Trypsinogen was not crystallized.

Concentrations of active phage in various fluids are given as numbers of plaques $/ \mathrm{ml}$. and those of viable bacteria as numbers of colonies $/ \mathrm{ml}$. The fluids for phage assay were appropriately diluted in a $\mathbf{2 4} \mathrm{hr}$. liquid culture of the host bacteria, and those for bacterial assay in the sterile liquid medium. The diluted fluids were then plated by mixing $1 \mathrm{ml}$. of each with $9 \mathrm{ml}$. of melted $0.7 \%$ agar medium cooled to $42^{\circ}$ and pouring into Petri dishes of $8 \mathrm{~cm}$. diameter. Plaques were counted after 2 days of incubation at $25^{\circ}$; bacterial colonies after $\mathbf{5}$ days of incubation.

The work was complicated by the presence in the nutrient media of materials that reacted with clupein to form precipitates which settled under gravity or an opalescence that could be removed by centrifugation for $20 \mathrm{~min}$. at c. 10,000 r.p.m. Most of the experiments were made with the strain 317 of nodule bacteria grown in the medium introduced by Demolon \& Dunez (1935) to isolate rhizobium bacteriophages from the soil. In addition to inorganic salts, the medium contained an extract from lucerne roots. (The medium was modified by using half the amount of the extract, and it was clarified by filtration.) The medium became opalescent on adding clupein and all the material responsible for this opalescence could be removed by adding $0 \cdot 1 \mathrm{mg}$. clupein sulphate $/ \mathrm{ml}$. of medium, and then centrifuging.

The other medium used was a nutrient broth used with Escherichia coli and with Staphylococcus aureus, which were studied only for the bactericidal effect of clupein. Additions of clupein sulphate to this medium produced an abundant precipitate, and at least $0.6 \mathrm{mg}$. clupein sulphate $/ \mathrm{ml}$. of the medium were needed to remove all the material which precipitated with clupein. This material protected the bacteria in broth from any detectable effect by $0.05 \%$ clupein sulphate, and tests for bactericidal effects were therefore made with bacteria suspended in physiological saline. The nodule bacteria were not protected in the nutrient medium of Demolon \& Dunez from the effects of as little as $0.0015 \%$ clupein sulphate. All the experiments with the nodule bacteria and with the bacteriophage were, therefore, done in this medium, and it has to be borne in mind that some proportion of the added clupein was probably bound by materials present in the medium, so that only part was responsible for the effects described below. 


\section{RESULTS}

\section{Analysis of clupein and hydrolysis by trypsin and chymotrypsin}

The amino acids of clupein were identified by paper chromatography. Clupein sulphate $(50 \mathrm{mg}$.) was dissolved in $2.5 \mathrm{ml}$. of $6 \mathrm{~N}-\mathrm{HCl}$ and heated in a sealed tube for $24 \mathrm{hr}$. at $100^{\circ}$. Hydrochloric acid was removed by heating the solution at $100^{\circ}$ in vacuum, dissolving the dry residue in water and evaporating the water at $100^{\circ}$ in vacuum three times. The final residue was dissolved in $5 \mathrm{ml}$. $\mathrm{H}_{2} \mathrm{O}$ and $0.025 \mathrm{ml}$. of the solution was placed on a Whatman no. 1 filter paper for chromatographic analysis. The chromatogram was developed with phenol $+\mathrm{NH}_{3}$ in one direction, with 'collidine' in the other and stained with ninhydrin. In addition to the spots corresponding with the five amino acids known to occur in clupein (arginine, valine, proline, serine and alanine (Kossel \& Dakin, 1904; Waldschmidt-Leitz, Ziegler, Schäffner \& Weil, 1931)), three weaker spots were obtained corresponding to threonine, glycine and leucine or isoleucine. Colorimetric determination of arginine in the clupein hydrolysate by Weber's modification of Sakaguchi's method (Weber, 1930) showed that the arginine content of clupein was about $80 \%$, which agrees with previous statements that clupein contains twice as many residues of arginine as of all other amino acids taken together.

Hydrolysis of clupein by trypsin and chymotrypsin was examined by adding $0.5 \mathrm{ml}$. of a $0.5 \%$ solution of trypsin or chymotrypsin (or of a mixture of equal volumes of the two) to $4.5 \mathrm{ml}$. of a $2 \%$ solution of clupein sulphate at $\mathrm{pH} \mathbf{7 \cdot 2}$, and incubating for $48 \mathrm{hr}$. at $37^{\circ}$. In controls water was substituted for enzyme solutions or for the solution of clupein sulphate. After incubation $0.01 \mathrm{ml}$. of each solution was placed on filter-paper for one-dimensional chromatography and the remainder was used for formol-titration. This was done by adjusting the $\mathrm{pH}$ value (measured with a glass electrode) to $7 \cdot 0$ in all the solutions, adding $2.5 \mathrm{ml}$. of a $20 \%$ solution of formaldehyde at $\mathrm{pH} \mathbf{7 \cdot 0}$, and titrating back to $\mathrm{pH} 7.0$ with $0.02 \mathrm{~N}-\mathrm{NaOH}$. The amounts of $0.02 \mathrm{~N}-$ $\mathrm{NaOH}$ used were: none with control solutions containing the enzymes alone; $0 \cdot 8 \mathrm{ml}$. with the control containing clupein sulphate alone; 5.7, 3.7 and 5.7 ml. respectively with solutions of clupein sulphate which had been incubated with trypsin, with chymotrypsin, and with the two enzymes together. Thus chymotrypsin split only about a half of the peptide bonds in clupein that were split by trypsin, which agrees with previous observations made by other methods (Waldschmidt-Leitz \& Kofranyi, 1935).

The chromatogram of the clupein hydrolysates and of the controls was developed for $48 \mathrm{hr}$. with a mixture of $10 \mathrm{vol}$. water-saturated $n$-butanol + 1 vol. glacial acetic acid, with enough water added to the mixture just to reach saturation, and stained with ninhydrin. Pl. 1, fig. 1, shows only a region of the upper part of the chromatogram; the lower part contained no spots. No spots appeared anywhere when the enzymes alone were run. Pl. 1, fig. 1, also shows the spot produced by $0.01 \mathrm{ml} .0 .1 \%$ arginine, and the positions of other spots are given below in terms of $\boldsymbol{R}_{\text {arg }}$ values in relation to the position of the arginine spot. All the spots were purple, though varying intensity. 
Unhydrolysed clupein gave a very faintly stained spot with $\boldsymbol{R}_{\text {arg }}=0$. Clupein hydrolysed by chymotrypsin produced two intensely stained overlapping spots with $R_{\text {arg }}$ values of 0 and $c .0 \cdot 15$, and a few very faintly stained spots. Clupein hydrolysed by trypsin produced two still more intensely stained spots with $R_{\text {arg }}$ values of $c \cdot 0 \cdot 15$ and $1 \cdot 0$, and a few faintly stained spots. The most intensely stained spot with $\boldsymbol{R}_{\text {arg }}=\mathbf{1} \cdot \mathbf{0}$ was probably produced by free arginine split by trypsin from clupein. A colorimetric determination of arginine by the modified Sakaguchi's method in a water extract from a section of another non-stained chromatogram showed that about one-fifth of the total arginine of trypsin-hydrolysed clupein was in the area corresponding with the free arginine spot. With the solvent used arginine was the slowest of all the amino acids contained in clupein, and as there were no spots below that of arginine, this was the only free amino acid split from clupein by trypsin in a detectable amount. The spots above the arginine spot were, therefore, produced by peptides, most of which corresponded with the $\boldsymbol{R}_{\text {arg }}$ value of c. 0.15. Chymotrypsin did not split off any free amino acids in detectable amounts and broke clupein into peptides, most of which corresponded with the $R_{\text {arg }}$ values of 0 and $\mathbf{0} \cdot 15$. The chromatogram of clupein hydrolysed by trypsin and chymotrypsin together did not differ from that of clupein hydrolysed by trypsin alone.

According to Bergmann (1942) chymotrypsin requires for its activity the presence in its substrates of a tyrosine or phenylalanine residue. As clupein has no such residues and is hydrolysed by chymotrypsin, Bergmann's definition of requirements of chymotrypsin is too narrow. The fact that trypsin splits all the bonds in clupein which can be split by chymotrypsin plus some that are not, also conflicts with Bergmann's classification of proteolytic enzymes, according to which trypsin differs from chymotrypsin in the ability to split different peptide bonds.

\section{Effect of clupein on numbers of bacterial colonies and on numbers of plaques}

To find the maximum concentration of clupein which did not affect the results of the assays for viable bacteria and active phage in the agar medium, $0.5 \mathrm{ml}$. vol. of solutions of clupein sulphate at different concentrations, or $0.5 \mathrm{ml}$. of water, were added to a series of tubes each containing $9 \mathrm{ml}$. of melted agar medium cooled to $42^{\circ}$. When effects on numbers of bacterial colonies were to be tested, $0.5 \mathrm{ml}$. of a $24 \mathrm{hr}$. liquid bacterial culture diluted $1 / 10^{5}$ was then added to each tube. When effects on numbers of plaques were to be tested, the addition was $0.5 \mathrm{ml}$. of undiluted liquid bacterial culture containing phage stock culture diluted $1 / 10^{7}$. The contents of the tubes were then poured into Petri dishes and incubated at $25^{\circ}$. Plaques were counted after 2 days of incubation and bacterial colonies after 5 days. (Addition of sufficiently high concentrations of clupein to the agar medium caused flocculation, but the floccules dispersed on stirring and solidified agar plates with clupein did not differ in appearance from control plates without clupein.)

Table 1 shows that the transition from complete suppression of plaques 
and colonies to full production of both was rather sharp when the concentration of clupein sulphate decreased from 0.05 to $0.025 \%$. Therefore, 'when assaying concentrations of viable bacteria or of active phage, care was taken not to introduce clupein sulphate in amounts that would exceed $0.025 \%$ in the agar medium.

Table 1. Effect of the presence of clupein in agar medium on numbers of bacterial colonies and on numbers of plaques

$\begin{array}{ccc}\begin{array}{c}\text { Concentrations of } \\ \text { clupein sulphate in } \\ \text { agar medium }\end{array} & \begin{array}{c}\text { Total numbers of } \\ \text { bacterial colonies } \\ \text { on four plates }\end{array} & \begin{array}{c}\text { Total numbers of } \\ \text { plaques on four } \\ \text { plates }\end{array} \\ 0 \cdot 05 & 0 & 0 \\ 0 \cdot 025 & 448 & 247 \\ 0 \cdot 0125 & 456 & 295 \\ 0 \cdot 00625 & 485 & 281 \\ 0 \text { (control) } & 444 & 275\end{array}$

Effects of clupein on host bacterium, on phage and on phage/host interaction in liquid medium

To test the effect of clupein on the bacteria in the liquid medium, $0.5 \mathrm{ml}$. of solutions of clupein sulphate at different concentrations were added to a series of tubes each containing $4.5 \mathrm{ml}$. of a $24 \mathrm{hr}$. bacterial culture in liquid medium. The mixtures were incubated at $25^{\circ}$, and samples withdrawn at intervals to assay viable bacteria. Table 2 shows that at and above a concentration

Table 2. Effect of clupein on host bacteria in the liquid medium

\begin{tabular}{|c|c|c|}
\hline \multirow{2}{*}{$\begin{array}{l}\text { Concentrations of } \\
\text { clupein sulphate in } \\
\text { the medium } \\
(\%)\end{array}$} & \multicolumn{2}{|c|}{$\begin{array}{l}\text { Concentrations of viable bacteria } \\
\text { (numbers of colonies/ml. culture) } \\
\text { after a period of incubation of }\end{array}$} \\
\hline & $1 \mathrm{hr}$. & 24 hr. \\
\hline $0 \cdot 05$ & 5 & 0 \\
\hline 0.016 & 170 & 3 \\
\hline 0.005 & $75 \times 10^{3}$ & $2 \times 10^{3}$ \\
\hline 0.0016 & $11 \times 10^{6}$ & $11 \times 10^{6}$ \\
\hline 0.0005 & $43 \times 10^{6}$ & $54 \times 10^{8}$ \\
\hline 0 (control) & $41 \times 10^{6}$ & $79 \times 10^{6}$ \\
\hline
\end{tabular}

The initial concentration of viable bacteria was about the same as in the control after $1 \mathrm{hr}$. of incubation.

of $0.005 \%$ clupein killed the bacteria at a higher rate with increasing concentration. At $0 \cdot 0016 \%$ clupein acted bacteriostatically, and at $0.0005 \%$ it still slightly inhibited bacterial growth. The bacteria seem to be killed by much smaller concentrations of clupein in liquid than in agar medium (see Table 1). The difference may be due to more clupein combining with constituents of the agar medium than with those of the liquid medium, or to its relatively slow diffusion through agar. 
To determine whether clupein had any more general bactericidal action, two other bacteria, a strain of Escherichia coli and a strain of Staphylococcus aureus isolated from healthy human skin, were tested. When nutrient broth in which these organisms were grown contained $0.05 \%$ clupein sulphate, both bacteria grew at their normal rates. However, addition of clupein sulphate to this medium immediately produced a large precipitate; it seemed likely, therefore, that the bacteria had been protected from clupein because most of the latter had combined with some constituents of the medium. Indeed, when the bacteria were suspended in physiological saline and clupein sulphate was added to $0.05 \%$, all the Escherichia coli organisms and most of the staphylococci were killed during $3 \mathrm{hr}$. of incubation at $25^{\circ}$, forming no colonies when plated on agar medium.

Table 3. Effect of clupein on the bacteriophage

\begin{tabular}{|c|c|c|}
\hline \multirow{2}{*}{$\begin{array}{c}\text { Concentrations of } \\
\text { clupein sulphate in } \\
\text { the medium } \\
(\%)\end{array}$} & \multicolumn{2}{|c|}{$\begin{array}{c}\text { Concentrations of active phage } \\
\text { (numbers of plaques } / \mathrm{ml} .) \\
\left(\times 10^{-7}\right) \text { after }\end{array}$} \\
\hline & $24 \mathrm{hr}$. & $48 \mathrm{hr}$. \\
\hline 0.05 & 3 & 0.5 \\
\hline $0 \cdot 025$ & 6 & $1 \cdot 5$ \\
\hline 0.0125 & 17 & 9 \\
\hline $0 \cdot 00625$ & 30 & 28 \\
\hline $0 \cdot 003125$ & 52 & 41 \\
\hline 0 (control) & 66 & 63 \\
\hline
\end{tabular}

The initial phage concentration was the same as in the control.

The effect of clupein on the phage was tested by adding $0.5 \mathrm{ml}$. of solutions of clupein sulphate at different concentrations to a series of tubes each containing $4.5 \mathrm{ml}$. of undiluted phage stock culture. The mixtures were incubated at $25^{\circ}$ and samples were taken at intervals for assaying phage. Table 3 shows that when the concentration of clupein sulphate was $0.003 \%$ or higher, the phage activity of the preparation decreased with increasing concentration of clupein, though very slowly by comparison with the rates at which the bacteria were killed at the same concentrations of clupein (see Table 2).

The effect of clupein on phage multiplication was tested by adding $0.5 \mathrm{ml}$. of solutions of clupein sulphate at different concentrations to a series of tubes each containing $4 \mathrm{ml}$. of a $24 \mathrm{hr}$. bacterial culture in liquid medium and then adding to each tube $0.5 \mathrm{ml}$. of a phage stock culture at a dilution of $1 / 10^{5}$. The mixtures were incubated at $25^{\circ}$ and samples were taken at intervals to assay phage. Comparison of the results in Table 4 with those in Table 2 shows that phage multiplication remained unaltered only at a concentration of clupein at which bacterial growth also remained almost unaffected $(0.0005 \%)$. At a concentration at which clupein was bacteriostatic $(0.0016 \%)$ phage multiplied but more slowly than in the absence of clupein. Finally, at bactericidal concentrations of clupein $(0.005 \%$ and above) phage activity decreased in a manner similar to that of phage alone exposed to clupein. 
To determine whether clupein affected only some initial stage of phage/host interaction, such as combination between phage and host, or whether it also interfered with further stages of the interaction, bactericidal amounts of clupein sulphate were added to the bacterial cultures which had been incubated with phage for $30 \mathrm{~min}$. at $25^{\circ}$, so that most of the phage had already combined with bacteria. The mixtures were further incubated for $3.5 \mathrm{hr}$., by which time infected organisms would normally have lysed and the concentration of phage in the medium would have increased about 100 -fold. Not only was there no

\begin{tabular}{|c|c|c|}
\hline \multirow{2}{*}{$\begin{array}{c}\text { Concentrations of } \\
\text { clupein sulphate in } \\
\text { the medium } \\
(\%)\end{array}$} & \multicolumn{2}{|c|}{$\begin{array}{l}\text { Concentrations of active phage } \\
\text { (numbers of plaques } / \mathrm{ml} \text {.) after }\end{array}$} \\
\hline & $4 \mathrm{hr}$. & $24 \mathrm{hr}$. \\
\hline $0 \cdot 05$ & 220 & 40 \\
\hline $0 \cdot 016$ & 440 & 140 \\
\hline 0.005 & 550 & 410 \\
\hline 0.0016 & 10,000 & $83 \times 10^{6}$ \\
\hline 0.0005 & 105,000 & $34 \times 10^{8}$ \\
\hline 0 (control) & 96,000 & $31 \times 10^{8}$ \\
\hline
\end{tabular}

The initial phage concentration was 750 plaques $/ \mathrm{ml}$.

increase in the concentration of phage but there was a decrease to less than one-tenth of the concentration obtained when clupein was added to the bacterial culture before adding phage. Thus the normal course of development of phage that had combined with bacteria before adding clupein was arrested and the phage became inactive. It still remains unknown whether phage multiplication inside bacterial cells was immediately arrested by clupein or whether phage continued to multiply but was not released because the bacteria did not lyse. It is clear, however, that the presence of clupein in bactericidal concentration prevented phage and bacteria from combining and also interrupted the normal course of phage development, if this had already started in the absence of clupein.

\section{Influence of sodium chloride on the effects of clupein}

Various effects of clupein on the phage, on the host bacterium and on their interaction might be results of combination of phage and of bacteria with clupein, caused by electrostatic attraction. Such combination is to some extent prevented or reversed by inorganic salts such as $\mathrm{NaCl}$ (Kleczkowski, 1946). It seemed possible, therefore, that some of the effects of clupein might be prevented or reversed by $2 \% \mathrm{NaCl}$, which is sufficient to clarify or to prevent the appearance of opalescence caused by the presence of clupein in the nutrient medium. However, the salt itself had bactericidal effect on the host bacteria, decreasing the concentration of viable organisms to $12 \%$ of the original during $24 \mathrm{hr}$. of incubation at $25^{\circ}$, and it completely inhibited phage multiplication in bacterial culture in liquid medium. The much more powerful bactericidal 
effect of $0.05 \%$ clupein sulphate remained unaffected by the salt. On the other hand, the phage itself was not affected by the salt. In the presence of $2 \% \mathrm{NaCl}$, phage activity of a stock culture was only halved by $0.05 \%$ clupein sulphate during $24 \mathrm{hr}$. of incubation at $25^{\circ}$, whereas it was decreased to $10 \%$ of the original in the absence of the salt. Phage inactivated by clupein was not reactivated by addition of salt.

\section{Effects of degradation products of clupein}

Tests similar to those made with clupein were also made with clupein hydrolysed into its constituent amino acids by $\mathrm{HCl}$. At a concentration equivalent to $0.05 \%$ of the original clupein sulphate the hydrolysate had no effect on the host bacteria, on the phage or on phage/host interaction. The constituent amino acids of clupein taken singly at $0.05 \%$ had also no effect. Similarly, hydrolysates produced by incubating clupein with trypsin had no effect on phage, but the chymotrypsin hydrolysate decreased phage activity of a stock culture to $75 \%$ of the original during $24 \mathrm{hr}$. of incubation at $25^{\circ}$. Phage activity was decreased to $12 \%$ in a simultaneous experiment by $0.05 \%$ intact clupein sulphate.

A test was then made to see whether activity of a phage culture, decreased to $12 \%$ of its original activity by incubation with intact clupein, could be restored by subsequent incubation with trypsin or chymotrypsin. One-tenth volume of a $0.5 \%$ solution of trypsin or chymotrypsin was added to the culture which had been incubated with intact clupein, and the culture was again incubated for $3 \mathrm{hr}$. at $37^{\circ}$. This resulted in a restoration of phage activity to $40 \%$ of the original where trypsin was added, and to $20 \%$ where chymotrypsin was added. It is possible, therefore, that the inactivation of phage by clupein was at least partially due merely to combination between phage and clupein, perhaps followed by aggregation. This would be reversed by trypsin and, to a smaller extent, by chymotrypsin. However, the part of the inactivating effect that was not reversed by the enzymes might be due to structural alterations in phage particles.

The investigation of the effect of clupein hydrolysed by trypsin and chymotrypsin on the phage/host interaction is complicated by the fact that these enzymes themselves affect the interaction. Chymotrypsin has no effect on the phage or the host bacteria separately but affects the interaction between the two, inactivating phage particles immediately after they have combined with bacteria (Kleczkowski \& Kleczkowski, 1954a,b). Trypsin behaves similarly and has about the same lowest effective concentration, namely about $0.001 \%$. It was, therefore, necessary not to exceed this concentration when testing for effects of hydrolysed clupein on phage/host interaction.

The following five mixtures, all at $\mathrm{pH} 7 \cdot 2$, were incubated for $24 \mathrm{hr}$. at $37^{\circ}$ :

(A) $0.9 \mathrm{ml} .5 .5 \%$ clupein sulphate $+0.1 \mathrm{ml}$. water;

(B) $0.9 \mathrm{ml} .5 .5 \%$ clupein sulphate $+0.1 \mathrm{ml} .0 .5 \%$ trypsin;

(C) $0.9 \mathrm{ml} .5 .5 \%$ clupein sulphate $+0.1 \mathrm{ml} .0 .5 \%$ chymotrypsin;

(D) $0.9 \mathrm{ml}$. water $+0.1 \mathrm{ml} .0 .5 \%$ trypsin;

(E) $0.9 \mathrm{ml}$. water $+0.1 \mathrm{ml} .0 .5 \%$ chymotrypsin. 
After the incubation all the fluids were diluted $1 / 25$ in water and $0.5 \mathrm{ml}$. of each diluted fluid, or $0.5 \mathrm{ml}$. water, was added to $4 \mathrm{ml}$. of a $24 \mathrm{hr}$. bacterial culture in liquid medium, followed either by $0.5 \mathrm{ml}$. of a phage stock culture at a dilution of $1 / 10^{5}$ when the effect on phage multiplication was tested, or by $0.5 \mathrm{ml}$. of the sterile liquid medium when the effect on the bacteria was tested. Thus, the final concentration of clupein sulphate in the medium was $0.02 \%$, enough for unhydrolysed clupein to have a powerful bactericidal effect and to prevent phage multiplication completely, whereas the concentration of the enzymes was $0.0002 \%$, i.e. below the limiting effective concentration for inhibition of phage/host interaction. The mixtures were incubated at $25^{\circ}$ and

Table 5. Effects of enzymic degradation products of clupein on multiplication of phage and of host bacteria

\begin{tabular}{|c|c|c|c|c|}
\hline \multirow[b]{2}{*}{ Tested materials } & \multicolumn{2}{|c|}{$\begin{array}{l}\text { Concentrations of } \\
\text { active phage (numbers } \\
\text { of plaques/ml.) after }\end{array}$} & \multicolumn{2}{|c|}{$\begin{array}{l}\text { Concentrations of } \\
\text { viable bacteria } \\
\text { (numbers of } \\
\text { colonies } / \text { ml.) after }\end{array}$} \\
\hline & $4 \mathrm{hr}$. & $24 \mathrm{hr}$. & $3 \mathrm{hr}$. & $24 \mathrm{hr}$. \\
\hline Intact clupein (mixture A) & 910 & 210 & 210 & 0 \\
\hline $\begin{array}{l}\text { Clupein hydrolysed by trypsin } \\
\text { (mixture B) }\end{array}$ & $14 \times 10^{4}$ & $34 \times 10^{8}$ & $6 \times 10^{7}$ & $10 \times 10^{7}$ \\
\hline $\begin{array}{l}\text { Clupein hydrolysed by chymotrypsin } \\
\text { (mixture C) }\end{array}$ & 970 & $85 \times 10^{3}$ & $5 \times 10^{7}$ & $6 \times 10^{7}$ \\
\hline Trypsin alone (mixture $\mathrm{D}$ ) & $13 \times 10^{4}$ & $35 \times 10^{8}$ & $6 \times 10^{7}$ & $11 \times 10^{7}$ \\
\hline Chymotrypsin alone (mixture $\mathrm{E}$ ) & $15 \times 10^{4}$ & $31 \times 10^{8}$ & $5 \times 10^{7}$ & $11 \times 10^{7}$ \\
\hline Control (water) & $13 \times 10^{4}$ & $33 \times 10^{8}$ & $6 \times 10^{7}$ & $10 \times 10^{7}$ \\
\hline
\end{tabular}

The initial concentration of phage was 1320 plaques $/ \mathrm{ml}$, and that of viable bacteria was about the same as in the control after $3 \mathrm{hr}$. incubation.

samples were taken at intervals for assays. Table 5 shows that clupein hydrolysed by trypsin had no effect either on phage multiplication or on bacterial multiplication. Clupein hydrolysed by chymotrypsin had no bactericidal effect, but it had a bacteriostatic effect and it inhibited phage multiplication, completely during the first $4 \mathrm{hr}$. and considerably during the following $20 \mathrm{hr}$.

The chymotrypsin hydrolysate of clupein interfered with combination between phage and host. This was demonstrated by adding the hydrolysate to a bacterial culture, then adding phage, incubating the mixture for $30 \mathrm{~min}$. at $25^{\circ}$, sedimenting the bacteria by centrifugation for $20 \mathrm{~min}$. at 10,000 r.p.m. and assaying phage in the supernatant fluid and in the resuspended sediment. Most of the phage remained in the supernatant fluid, whereas in a control experiment, in which water was substituted for the hydrolysate, most of the phage was in the sediment.

To examine whether further stages of phage/host interaction were interfered with, the hydrolysate was added to a phage + bacteria mixture which had previously been incubated for $\mathbf{3 0} \mathrm{min}$. so that most phage particles had already combined with bacteria; phage was assayed after a further $3.5 \mathrm{hr}$. of incubation, by which time normally all the infected bacteria would have lysed. Almost as much phage was detected as in a control experiment without the 
hydrolysate, i.e. about a 100-fold increase in phage concentration had occurred. Thus the cycle of phage/host interaction, which had already started, proceeded to completion in the presence of the hydrolysate.

Thus, none of the constituent amino acids of clupein or the peptides produced by trypsin showed any of the effects of clupein on phage or bacteria, whereas the larger peptides produced by chymotrypsin did show some effect. The size of molecules may be important, but the effects might also be functions of some configurations that were destroyed when some peptide bonds were broken.

\section{Sedimentation and resuspension of phage + clupein complex}

All centrifugations referred to below were done in an angle centrifuge at c. 10,000 r.p.m. for $20 \mathrm{~min}$. (about $6000 \mathrm{~g}$ at the middle of the tube). Centrifugation of a phage stock culture did not sediment phage appreciably, but most of the phage sedimented from cultures to which $0.02-0.05 \%$ clupein sulphate had been added. The clupein sulphate made the culture opalescent, and centrifugation separated a sediment and left a clear supernatant fluid. By resuspending the sediment various amounts of phage activity were recovered, the amounts depending on the kind of suspending medium used and on other factors (e.g. concentration of clupein; length of time of exposure of phage to clupein). Usually, less than $10 \%$ of phage activity was recovered when the sediment was suspended in water, up to $50 \%$ in $2 \% \mathrm{NaCl}$ and up to $80 \%$ in the nutrient medium. Up to $80 \%$ was also regained when the sediment was suspended in a $0.1 \%$ water solution of trypsin and incubated for a few hours at $37^{\circ}$ at about $\mathrm{pH} \%$.

The presence of $2 \% \mathrm{NaCl}$ in a phage culture or hydrolysis of clupein by trypsin or chymotrypsin before adding it to the culture, prevented the culture from becoming opalescent and phage from becoming sedimentable by centrifugation.

Most of the material sedimented from a phage culture is not phage, for about as much sediment is obtained from the sterile medium. The quantity of sediment was decreased by incubating the culture with trypsin or chymotrypsin before adding clupein. The opalescence produced by adding clupein to such cultures decreased on incubation and disappeared after $c$. $1 \mathrm{hr}$. at room temperature. The amount of phage sedimentable by centrifugation also decreased with increasing length of time between the addition of clupein and centrifugation of the fluid; no phage was sedimented when the opalescence had disappeared.

Phage can be concentrated by suspending the sediment in a volume of fluid smaller than the volume of the original culture. The presence of much nonphage material limits the extent to which phage can be thus concentrated, for suspensions become inconveniently thick when more than a ten-fold concentration is attempted. When resuspended sediments were incubated at $25^{\circ}$ the phage titre decreased at a rate inversely proportional to the volume of suspending fluid. For example, phage sedimented after addition of clupein sulphate to $0.05 \%$ and suspended in a volume of nutrient medium equal to 
Journal of General Microbiology, Vol. 14, No. 2

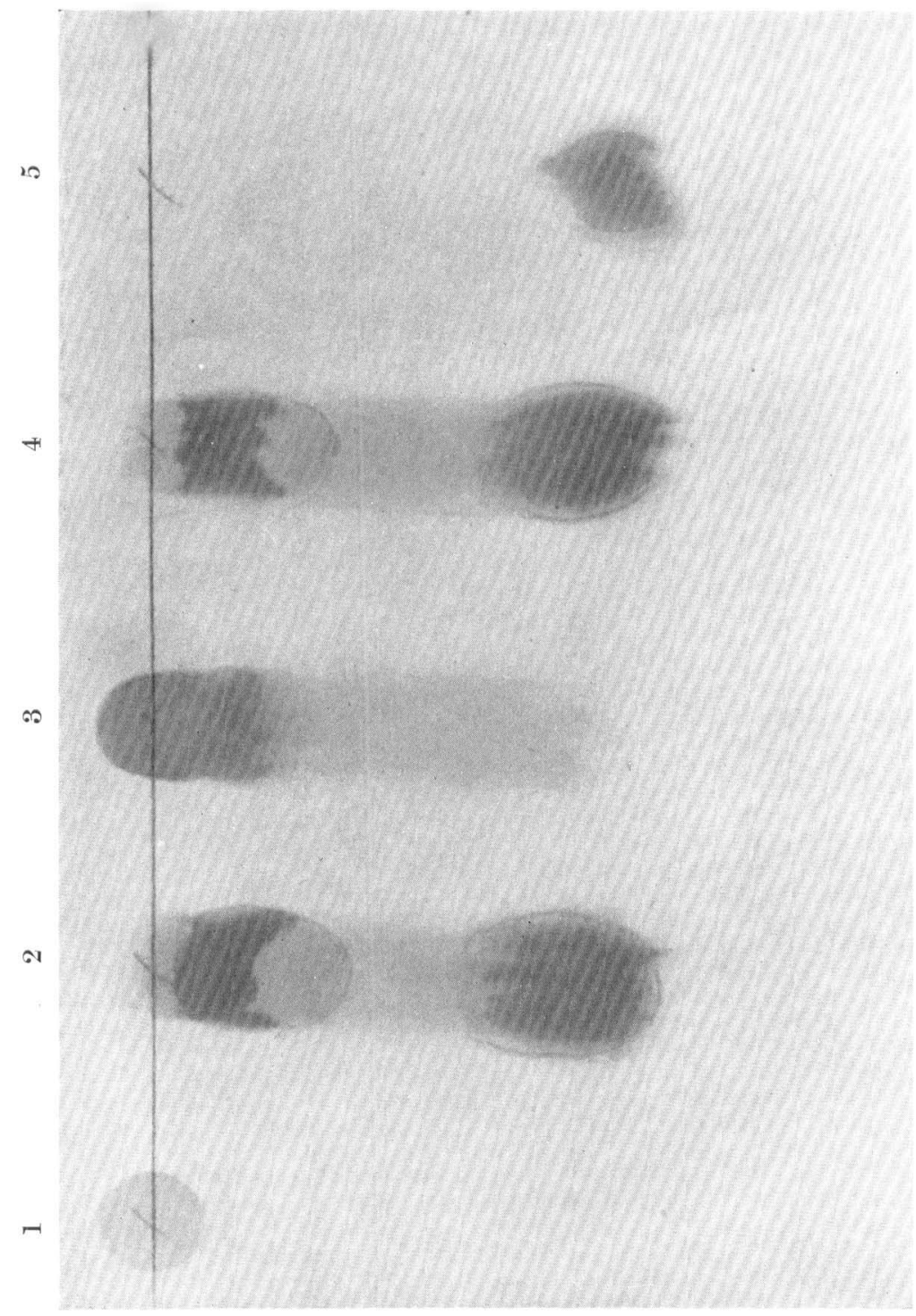

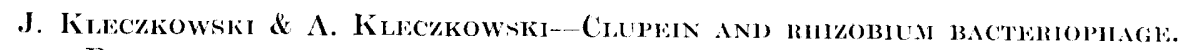
PIATE 1

(Facing $p .459)$ 
one-tenth that of the original culture, showed seven times more phage activity than the original culture, but the activity fell to one-sixth after $\mathbf{2 4} \mathrm{hr}$. of incubation at $25^{\circ}$, while that of the original culture remained unchanged. When the sediment was suspended in a volume of the nutrient medium equal to that of the original culture, phage activity of the suspension was about $70 \%$ of that of the original culture, and was only halved after $24 \mathrm{hr}$. of incubation at $25^{\circ}$. Presumably the inactivation was caused by clupein in the sediment and was correlated with its concentration. The decrease in phage activity of the suspensions was prevented by the addition of trypsin and incubation for a few hours at $37^{\circ}$ at $c . \mathrm{pH} 7$; but as trypsin, as well as clupein, affects phage/host interaction, the method has only slight value for fractionating and concentrating the phage.

\section{REFERENCES}

Bawden, F. C. \& Pirie, N. W. (1937). The isolation and some properties of liquid crystalline substances from solanaceous plants infected with three strains of tobacco mosaic virus. Proc. roy. Soc. B, 123, 274.

Bergmann, M. (1942). A classification of proteolytic enzymes. Advanc. Enzymol. 2, 49.

Chambers, L. A. \& Henle, W. (1941). Precipitation of active influenza A virus from extra-embryonic fluids by protamine. Proc. Soc. exp. Biol., N.Y., 48, 481.

Demolon, A. \& Dunez, A. (1935). Recherches sur la rôle du bactériophage dans la fatigue des luzernièrs. Ann. agron., Paris, N.S. 5, 89.

Kleczkowski, A. (1946). Combination between different proteins and between proteins and yeast nucleic acid. Biochem. J. 40, 677 .

Kleczkowski, J. \& Kleczkowski, A. (1954a). A study of the mechanism of inhibition of bacteriophage multiplication by chymotrypsin. J. gen. Microbiol. 10, 285.

Kueczkowski, J. \& KLeczkowski, A. (1954b). The effect of ribonuclease on phagehost interaction. J. gen. Microbiol. 11, 451.

Kossel, A. \& Dakin, H. D. (1904). Über Salmin und Clupein. Z. physiol. Chem. 41, 407.

Northrop, J. H., Kunitz, M. \& Herriot, R. M. (1948). Crystalline Enzymes, 2nd ed. New York: Columbia University Press.

Thompson, W. H. (1900). Die physiologische Wirkung der Protamine und ihrer Spaltungsprodukte. Z. physiol. Chem. 29, 1.

Waldschmidt-Leitz, E. \& Kofranyi, E. (1935). Über die Struktur der Protamine. II. Strukturaufklärung des Clupeins. Z. physiol. Chem. 236, 181.

Waldschmidt-Leitz, E., Ziegler, F., Schäffner, A. \& Weil, L. (1931). Über die Struktur der Protamine. I. Protaminase und die Produkte ihrer Einwirkung auf Clupein und Salmin. Z. physiol. Chem. 197, 219.

Warren, J., Weil, M. L., Russ, S. B. \& Jeffries, H. (1949). Purification of certain viruses by use of protamine sulfate. Proc. Soc. exp. Biol., N.Y., 72, 662.

Warren, J., Weil, M. L., Russ, S. B. \& Jeffries, M. (1950). Applications of protamine precipitation in purification of certain viruses. Fed. Proc. 9, 394.

Weber, C. J. (1930). A modification of Sakaguchi's reaction for quantitative determination of arginine. J. biol. Chem. 86, 217.

\section{EXPLANATION OF PLATE}

Fig. 1. The chromatograms of (from left to right): (1) intact clupein sulphate; (2) clupein sulphate hydrolysed by trypsin; (3) clupein sulphate hydrolysed by chymotrypsin, (4) clupein sulphate hydrolysed by trypsin and chymotrypsin; (5) arginine.

(Received 14, October 1955) 